\title{
Teaching Czech German Refugees at Tate Creek, British Columbia, During World War II
}

\section{Helen Raptis}

\section{ABSTRACT}

This paper explores the experiences of two teachers of Czech German refugees who settled at Tate Creek, British Columbia after Hitler's annexation of the Sudetenland in 1938. In an era which pre-dates the genesis of the term "English as a Second Language" (ESL), Amy (Brown) Dauphinee and Celia (Stickney) Dowding employed pedagogical techniques that closely resembled those advocated by today's ESL experts. This research also raises questions about the roles schools played in Canada's war effort. The extent to which children and teachers engaged in war-related activities depended on many factors, including a teacher's personal qualities and skills as well as the nature of the community.

\section{RÉSUMÉ}

Cet article traite des expériences de deux enseignantes qui ont travaillé auprès de réfugiés tchèques d'origine allemande installés à Tate Creek, Colombie-Britannique, après l'annexion par l'Allemagne des Sudètes en 1938. À une époque précédant l'apparition du terme "anglais langue seconde (ASL) " Amy (Brown) Dauphinee et Celia (Stickney) Dowding employaient des techniques pédagogiques qui s'apparentaient à celles utilisées de nos jours par les experts d'ASL. L'étude soulève également des questions quant au rôle joué par les écoles dans l'effort de guerre canadien. L'étendue de l'engagement du personnel et des élèves dans des activités liées à la guerre dépendait de plusieurs facteurs dont la personnalité et les aptitudes des enseignants, ainsi que du caractère de la communauté où l'école se trouvait.

Early in 1939, the Canadian government struck a deal with Britain to accept up to 3,500 Czechoslovakian refugees from "physically fit families" who had fled the Sudetenland following Hitler's annexation. By the spring, 518 settlers had arrived at Tate Creek, in northeastern British Columbia (BC). ${ }^{1}$ The children of these refugees had to be schooled. In an era that predates the birth of the term "English as a second language (ESL)," the refugees' presence prompts an important question. How did teachers without specific ESL training work with non-English-speaking refugees? This paper explores the experiences of two teachers who worked with the refugee children and also raises some basic questions about the impact of World War II on Canadian schools. 
There is substantial research literature indicating that World War II had considerable influence on Canadians, whether they enlisted to fight abroad or opted to serve from the "homefront." Approximately 920,000 people joined the armed forces with 100,000 enrolling in the air force, 93,00 in the navy, and 727,000 in the army. ${ }^{2}$ No less significant was the effect of the war on educational policy and programming. Robert Patterson has noted that the passage of the 1943 national Physical Fitness Act was intended to promote wellness among school children through physical education, health inspections, and increased nutritional emphasis in home economics courses. ${ }^{3}$

Schools were considered optimal sites for instilling nationalistic sentiments and activities. Canadian policy-makers encouraged students and teachers to support the war effort by collecting scrap materials, purchasing war savings stamps and establishing local branches of the Junior Red Cross. ${ }^{4}$ In 1940, the BC government passed a regulation that high schools establish cadet corps, wherever possible, and that teachers swear an oath of allegiance. ${ }^{5}$ Children and teachers were also required to salute the flag and "sing the national Anthem" at least once a week. ${ }^{6}$ Trail high school cadets undertook military drills using Ross rifles whereas Vancouver students used readilyavailable wooden guns. ${ }^{7}$ Inspector Roy Shields reported in 1940 that almost 100 percent of New Westminster's senior high school student body enrolled in cadet training. ${ }^{8}$ That same year, notes James London, Education Minister H.G.T. Perry agreed to have schools post the Ten Commandments in "prominent locations in public schools." ${ }^{9}$ By 1944, provincial legislation was eventually passed to permit schools to open with Bible readings followed by recitation of the Lord's Prayer.

In the spring of 1941, Canadian policy makers began urging schools to facilitate students' transitions to war-related work. ${ }^{10}$ Officials across the nation sent circulars to school principals advising that technical courses should increasingly emphasize skills that would transfer to industries contributing to the war effort. ${ }^{11}$ While boys were to craft model aircraft, girls were encouraged to attend home economics classes increasingly focused on knitting socks, scarves, and afghans for servicemen overseas. ${ }^{12}$ In addition, high school students in good standing were permitted to leave school in the fall to work on farms experiencing labour shortages, slightly offsetting an acute teacher shortage. ${ }^{13}$

Since much of the research on wartime schooling has tended to rely on "official" information sources, such as curriculum documents and government directives, one is left with the impression that schools were considerably reshaped by Canada's involvement in World War II. ${ }^{14}$ Given the existing research base, it is difficult to determine how widely policy-makers' directives were adopted in schools across the nation. ${ }^{15}$ Evidence from BC suggests that reform was less widely implemented than one might expect from official government directives. For example, in BC, Industrial Arts shops were established in about nine of the province's roughly 600 districts during wartime. ${ }^{16}$ Despite policy-makers' best intentions, as the war dragged on fewer high students enrolled in Industrial Arts due, in part, to a shortage of teachers with industrial skills; "several of the smaller centres had to remain closed." 17

Recollections from former school children suggest that a widespread sense of patriotism arose "that was never generated again." 18 A participant in Emilie 
Montgomery's study of BC children who lived through the war recalled her teacher exposing students to war news and to Hitler's speeches on a class radio. Some students remember collecting war savings certificates, enduring marching drills during physical education classes, and planting victory gardens from which some produce was sent overseas. Other studies have yielded memories of discussing the war's causes in Social Studies and tracing military advances on maps of Europe that had begun to grace classroom walls. ${ }^{19}$ Mary Peate's teen years memoir noted that "Canadian public school kids, wearing Red Cross lapel buttons, collected money ... by going door to door selling ... calendars." ${ }^{20}$ In a tribute to Generation "M" (for mature) by Robert Collins, one woman noted that "at school, when you'd finished a page on your exercise paper, you'd turn it upside down and write in between the lines, to save paper." ${ }^{21}$

Despite the volume of war-related literature, few publications focus on teachers' memories of their work during the war. One of the most comprehensive is Elizabeth McLachlan's moving compilation, With Unfailing Dedication: Rural Teachers in the War Years. In it, one teacher recalled her pupils' anticipation of Friday afternoon meetings of the Junior Red Cross Club where they learned "about citizenship and health... They raised money and performed activities for various goodwill projects locally and abroad... it was exciting to write to pen-pals from Junior Red Cross organizations throughout the world." ${ }^{2}$

Nevertheless, histories of both students' and teachers' wartime recollections tend not to be categorized by geographic area (such as rural versus urban, or coastal versus central Canada) or school level (elementary versus secondary). ${ }^{23}$ Consequently, there is an implied "unity of purpose and experience" among all teachers and children across the nation. ${ }^{24}$ This is problematic, given that the war had lesser or greater influence on differing regions and peoples across the country. ${ }^{25}$ We know, for example, that the education of students of Japanese heritage was seriously interrupted with their forcible removal from the coast of British Columbia. ${ }^{26}$ Elsewhere, the Manitoba government cancelled the teaching certificates of pacifist Mennonite teachers who refused to participate in ward bond drives. ${ }^{27}$ More problematic still, some literature conflates the experiences of children and teachers both inside and outside of school, perhaps implying that the schools played a more active role in the war effort than they may have in reality. ${ }^{28}$

American curriculum historian O.L. Davis has called for more scholarship on World War II and schools, challenging researchers to "focus on the varieties of schooling in individual communities of different sizes and social compositions." ${ }^{29}$ In response to Davis's challenge, I have been researching education in British Columbia (BC) during the war era. To obtain "official" perspectives I have examined curricular documents, government directives, memos and other publications of the Department of Education, as well as newspapers and magazines. "Unofficial" views have been collected from roughly two-dozen teachers who taught in the province between 1939 and 1945. In this paper, I focus on the experiences of two teachers, Amy Brown (née Dauphinee) and Celia Stickney (née Dowding) who taught at the refugee settlement at Tate Creek. I examine their experiences because little is known about how non-English-speaking populations experienced the war. Furthermore, their stories 
challenge the notion that, across the nation, children and teachers in schools were engaged in efforts to support the war. Although World War II seriously affected the teachers and pupils at Tate Creek School, none of their classroom time was devoted to Canada's war effort. Amy's and Celia's experiences suggest that the extent to which children and teachers in schools engaged in war-related nationalistic activities depended on the complex intersection of teachers' own skills and personal qualities and factors within the community.

\section{Tate Creek Background}

Members of Czechoslovakia's Sudeten German Social Democratic party vocally protested Hitler's annexation of Austria. When Chamberlain's appeasement policy resulted in Germany annexing the Sudetenland, large numbers of party members fled the region into eastern Czechoslovakia. Czech authorities worried about antagonizing Hitler by harbouring the refugees and so returned many to the Sudetenland where they eventually perished under the Nazis. ${ }^{30}$

Party executive members Wenzel Jaksch and Wilhelm (Willi) Wanka found the situation unacceptable and so flew to London to seek help. Labour Party officials and various private citizens welcomed them and developed a plan to evacuate the refugees to countries willing to take them in. ${ }^{31}$ The British and French governments supported the plan and loaned four million pounds to Czechoslovakia, a portion of which was reserved for refugee settlement. By spring 1939, the first group of settlers arrived at Tate Creek. ${ }^{32}$

The settlers did not directly handle the funds. Instead, Britain's Home Office administered a semi-public Czech Refugee Trust Fund, allegedly to prevent the money from finding its way into Nazi hands. ${ }^{33}$ Canada designated refugee settlement to the Canadian Pacific Railway's (CPR) Immigration and Colonization Department, which in turn assigned the task to its subsidiary the Canadian Colonization Association. Chief superintendent Major Fraser B. McConnell directly oversaw the settlement. ${ }^{34}$ Not "a man of compassion and understanding," McConnell treated the refugees with disdain, issuing food, clothing, tools, supplies and farm animals to the settlers as he saw fit. ${ }^{35}$

Many of the Sudeten refugees were urban and highly-skilled professionals, tradesmen, and artisans. Some resented McConnell's condescension. It took two years before the settlers were granted title to their land, although they had been led to believe that this would occur right away. Given that less than five percent had ever farmed before, their success as farmers was impressive. ${ }^{36}$

Although much of the Peace River region is considered highly fertile, ${ }^{37}$ the land at Tate Creek was not. It was part of Gundy Farm, an abandoned ranch that the Canadian Pacific Railway Company had acquired from the Canadian government as part of a deal to construct the first transnational rail line. By 1939, only 650 acres of the 21,000-acre settlement had been cleared for cultivation. The uncultivated area consisted of heavy bush, swampland and low-grade clay. ${ }^{38}$ In 1944 one resident argued that it was "the poorest country in the Peace River," lying in a frost belt and covered with muskeg. ${ }^{39}$ 


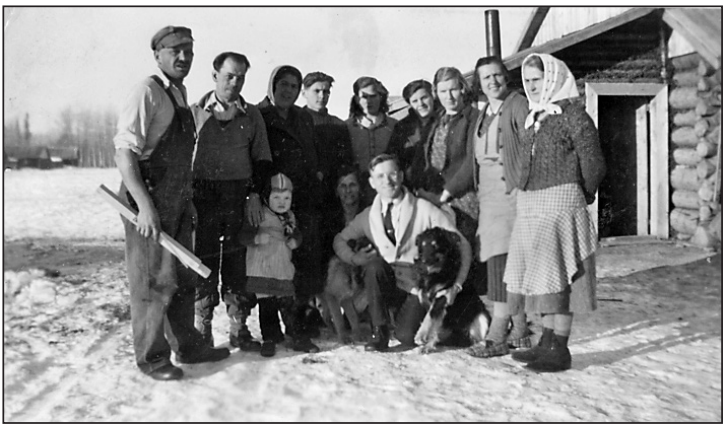

Figure 1: Sudeten German settlers, 1939. Courtesy Amy (Brown)

Dauphinee.

Upon arrival at the settlement, "the men swore and the women cried in disappointment." ${ }^{40}$ The refugees learned that the Colonization Association had not had time to complete adequate housing for all of the settlers who were forced, initially, in tents and train cars.

\section{Amy Brown (Dauphinee)}

On 3 September, 1939, Amy Brown (Dauphinee), a 19-year-old graduate of Vancouver's Provincial Normal School, arrived in Tate Creek to take up her first teaching position. ${ }^{41}$ Although trained to work with English-speaking elementary pupils, monolingual Amy - an active member of BC's Young Socialist League and keen political observer - was undaunted by the prospect of teaching 28 German-speaking students, aged 12 to $19 .{ }^{42}$ Amy would later attribute her courageous spirit to surviving the Depression's hardships and to the adventurous nature of her parents who had emigrated from Newfoundland to Vancouver. Her father, a sea captain, believed that women and men were equal and he encouraged Amy to engage in non-traditional pursuits. ${ }^{43}$

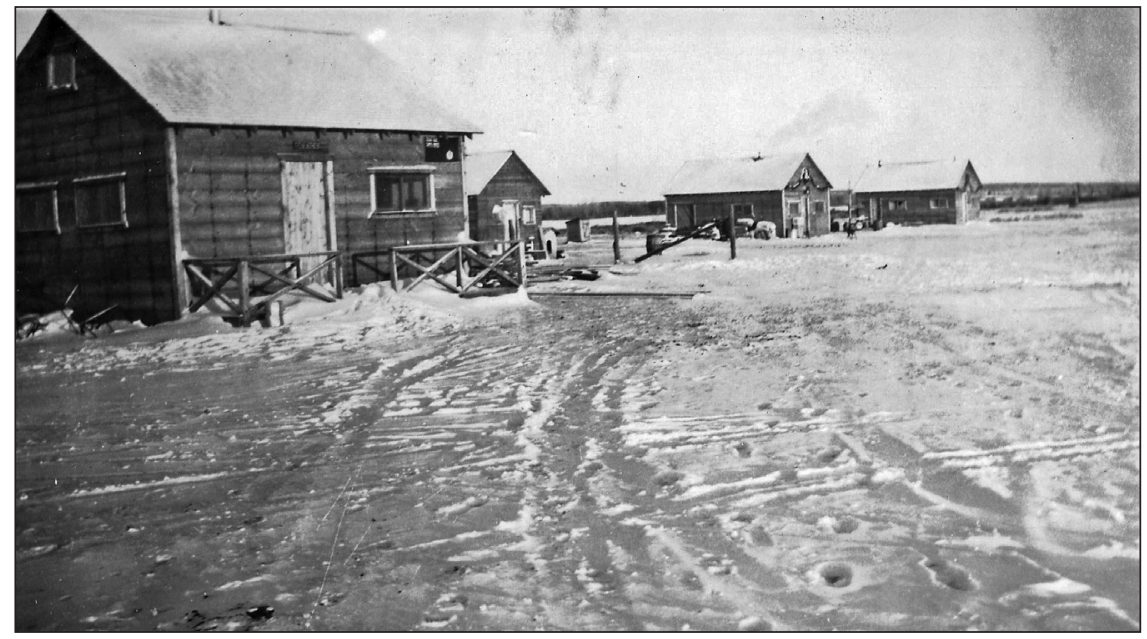

Figure 2: Refugees' cabins at Tate Creek settlement. Courtesy Amy (Brown) Dauphinee. 
When Amy arrived at Tate Creek, the two-room schoolhouse had not been built, so she took the opportunity to meet her pupils and their families. Though none of the children spoke English and Amy spoke no German, her willingness to connect with the community endeared her to the settlers and they befriended her immediately. By the time she began teaching at the end of September, she was a regular guest in the refugees' homes and at their social functions. Amy admired the refugees for opposing Nazism and advocating for themselves to the British and Canadian governments.

By visiting with the children's families, Amy learned much about the refugees' experiences. She learned that they, like her, were "strongly anti-fascist" and had been targeted by Hitler and the Gestapo. As a result, some of their family members had perished, as illustrated by the following story relayed to her by one of the parents:

They got word at union headquarters that the Gestapo was in town. The two brothers left the office and went to get their suitcases to head for the border. The younger brother said "my God, the membership list!" He told his older brother to go ahead and he would return to destroy the list since he was younger and could run faster. He made it back to destroy the list, but was caught trying to get out at the border and was shot...

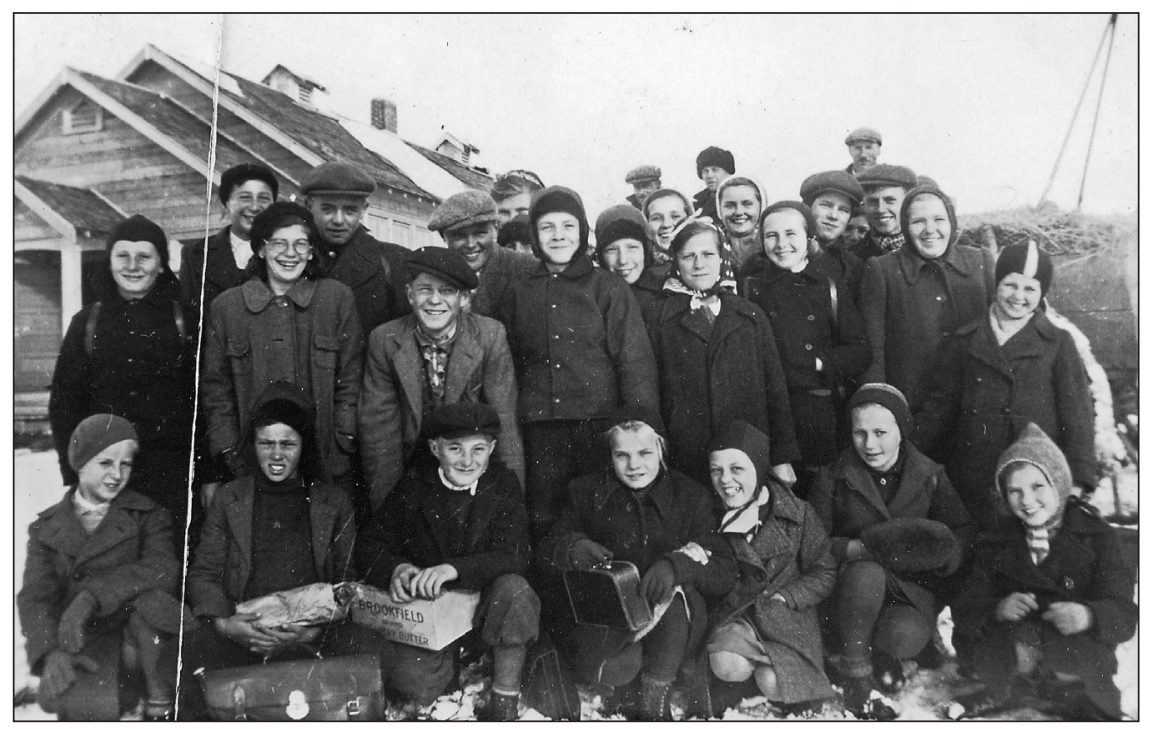

Figure 3: Amy Brown's first students at Tate Creek. Courtesy Amy (Brown) Dauphinee.

In addition to working with the children, Amy set up night classes to teach English to the adults in the community. More often than not, however, the classes turned into discussions of current events, including developments pertaining to the war in Europe, using newspaper clippings and radio broadcasts.

The only instructions Amy received upon arriving at Tate Creek were from the regional school inspector who directed her to "teach the students English." 
Well I didn't have any training, any ESL...So I had to figure out something and one night I was out walking down the road and I heard them singing. They had a choir group in the little church and there was a choir singing $\mathrm{O}$ Tannenbaum. I recognized the tune and it just struck me there that that's what we had in common. We had music. My first lesson was the O Tannenbaum with words in English on the blackboard. I found songs that we both sing and I started out that way. Since I had no special books, I just said to them we're going to have to start with grade 1 English... So I started with Dick and Jane. I labeled everything all around the classroom.

Amy's reading program centred on fairy tales, which students would retell or act out. She preferred fairy tales over government-prescribed textbooks, since students would have likely read many in German while living in Czechoslovakia.

Discipline proved challenging for the young teacher, given that Amy and her pupils were close in age.

I would say they were noisier... They were rambunctious kids. They weren't rude or defiant...Many of them were great soccer players and they were boisterous... But they lived under difficult times. We had a pot bellied stove and they would bring their lunches...you know, soup and stuff...they would bring them in syrup cans. And somebody put the lid on too tight and this one blew and every child went under the desk. And I'm standing there and this lid pops and suddenly you don't see the kids and they're all under the desk. And for a moment I thought, my God, of course...their background. Noise to them is bombing.

Amy would play soccer or baseball with her students or allow them to work on math to alleviate some of the children's stress from working in a foreign language all day.

Nevertheless, not everyone appreciated Amy's efforts. The community of refugees began to splinter over matters such as how to interact with the colonization administrators. While some preferred compliance to McConnell's demands, others rebelled. ${ }^{44}$ Amy recalled:

The Colonization Department took advantage of them. They were settled on land that Canadian farmers couldn't make a go of. They got a rotten deal. And they weren't going to take it lying down. And of course that's the kind of person that appeals to me... The group that I leaned towards, my friends and the ones that I liked were the rebels. I've always liked the underdog.

Miss Meade, Amy's co-worker and principal, who taught the seven to 11 year olds, disapproved of Amy's relationships and preferred to keep her distance from the families despite her ability to communicate better in German. She also made it clear that she wanted to minimize contact with Amy. Miss Meade had over twenty years of elementary teaching experience but she was a loner and rather than board with Amy she stayed outside of the perimeter of the settlement in her own trailer. 
Typical of rural schools of the era, the Tate Creek school consisted of two back-toback rooms connected by a thin door. ${ }^{45}$ This was not enough to prevent the noise in Amy's classroom from disturbing Miss Meade who visited the regional school inspector each week to report "on all the woes and all the mistakes Miss Brown made and how Miss Brown wasn't doing so well." What seemed to worry her most was Amy's attendance at the community dances where she would dance late into the night with the camp's single men. ${ }^{46}$

Soon after Christmas, the inspector informed Amy that she was to move to another school. Less than four months after beginning her teaching career, Amy was to begin a new position at North Swan School, approximately six miles from Tate Creek, but still within the Sudeten settlement area. ${ }^{47}$ When school opened in January, a dozen of Amy's students walked the six miles from Tate Creek to North Swan, demanding the return of Miss Brown. But the inspector held fast to his decision — which he eventually came to regret and for which he later apologized.

Though upsetting at the time, Amy's experience at Tate Creek profoundly shaped a teaching career that lasted until 1985. At the settlement, she quickly learned about the unsavory "political" aspects of working with difficult colleagues. She also learned that one of the most important elements of teaching is building good relationships with children and their families. "If you reach out to parents, they'll reach back,"she advises. Good teaching means being able to "put yourself in [your students'] shoes" and to do this you must know where they're coming from. "In those days you sank or swam on your own. There was no library to go to. There were no resources. It was sort of tough... But I managed to survive. I give a lot of credit to the support I got from the kids and the parents."

At first glance, it may seem curious that Amy has no recollection of engaging her pupils in activities to support Canada's war effort. Her only memories of the war's impact on school life were the stories her pupils shared of their harrowing escape from

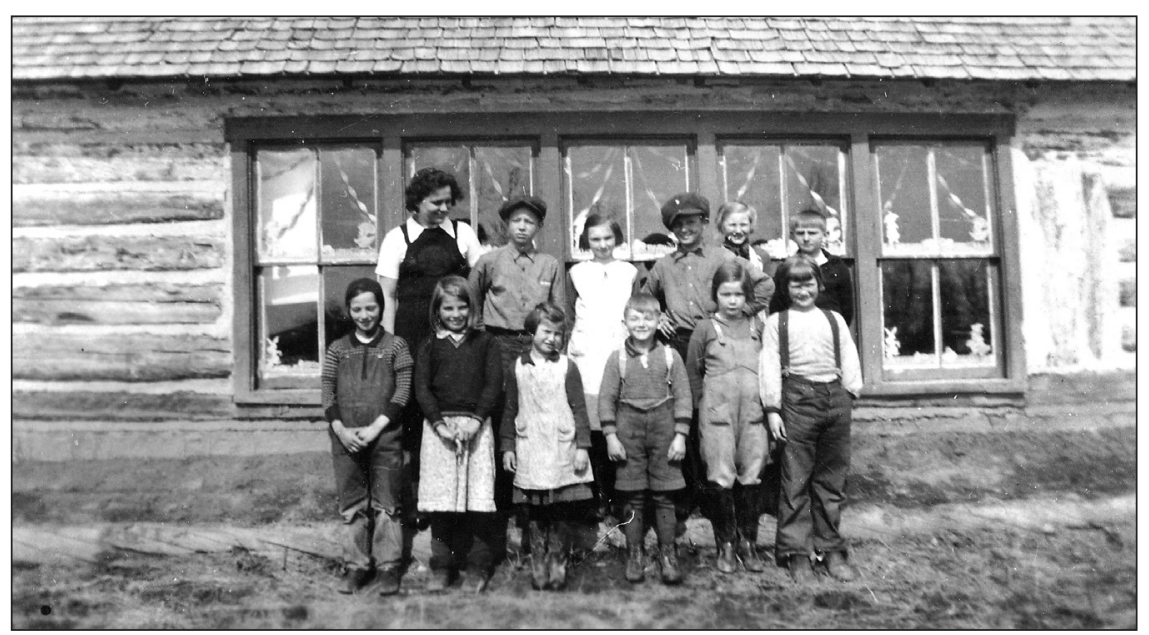

Figure 4: Amy and Czech German students at North Swan school. Courtesy Amy (Brown) Dauphinee. 
Hitler's advancing army. Asked why this was the case, Amy suggested that her role was to help the children and parents learn English and to adjust to a new life, one in which they found safety and peace of mind in contrast to the troubles they had fled. In such a context, Amy saw no place for collecting war savings stamps, salvaging scrap metal or collecting for the Junior Red Cross. Indeed, with the refugees surviving on a shoestring, there would have been precious little to collect.

At the end of the school year in 1940, Amy married Tim Dauphinee and eventually relocated to Ontario for Tim's work. In addition to teaching and raising a family of three, she was actively involved in her community. In 1971, she became the first woman elected to the Ontario Credit Union Board of Directors. For the work Amy and Tim did in co-founding the union's charitable foundation which distributed funds to women in developing countries to establish cooperatives, the union established the Amy and Tim Dauphinee Scholarship for graduate research on credit union movements.

Reflecting on her long career as a teacher and later vice-principal, Amy noted that one of the most important activities she undertook with her classes was to adopt two orphans from India who were supported annually by the children in Amy's classes. Along with providing financial support, Amy's students served as "surrogate family" for the orphans. Social studies lessons took shape as informative letters, artwork, and postcards destined for India. According to Amy, "you can play a tremendous role in [the children's] family, in their lives. These are your kids... your daytime kids... And I was their daytime mother." Clearly, Amy saw her role not in terms of preparing citizens of Canada, but of the world.

\section{Celia Stickney (Dowding)}

Four years after Amy's ordeal, Celia Stickney (Dowding) was hired to teach the refugee children at Tate Creek School. ${ }^{48}$ She was born in 1924 in Peace River, Alberta, but the family relocated to Beaverlodge in 1929 to take up cattle farming. She recalls her upbringing being happy and secure as her parents shielded her and two sisters from most hardships of the Depression. Celia attended Vancouver's Provincial Normal School in 1943-44 and upon completion of the program applied to teach in British Columbia's Peace River district, just over the border from her home in Beaverlodge. By the time she arrived at Tate Creek School, the population of school-aged pupils had declined to 37; so, as the sole teacher, she taught grades one through eight and oversaw two students completing grade nine by correspondence. She boarded with the Seidel family with whom she managed to communicate through "broken German, broken English, and lots of gestures.”

Without a teaching colleague with whom to confer, Celia welcomed the professional support of the regional inspector who helped to answer questions and solve problems. "Sometimes there was a book or some material that would have the answers in the back and they weren't right and I knew they weren't right... yet, how can you prove it? And the inspector was right there. Nothing but helpful." She also worked closely with Father Goetz, a Catholic priest, who spoke German and taught 
the children Catechism on Wednesday afternoons. ${ }^{49}$ Not being Catholic, Celia and a Jewish student would leave the room during the session. She was amused to overhear one of her students ask why Miss Stickney was not Catholic — to which Father Goetz apparently replied "oh, she can't help it" and carried on with his lesson. In addition to teaching Catechism, Father Goetz helped Celia to dig broad jump pits for sports day, to line the baseball field, and to arrange bingo games and other social activities for the community.

Celia's pupils were functioning at a basic level of English. She noted, however, that it was not easy to keep many students at different grade levels interested and busy. The secret to managing a multi-level one-room school, she explained, was to individualize reading, math and spelling so that students could work at their own pace. She "integrated" or combined subjects such as social studies, science, and physical education and grouped students by ability so that any topics not completed one year could be studied on alternate years. Managing in this way enabled Celia's older students to help younger ones as much as possible. The older students also kept the fire burning in the wood stove and, on the rare occasion, taught for Celia when she was ill!

Although the school was adequately equipped with textbooks and equipment, many of the next day's lessons had to be written up on the board. Because she walked one and a half miles to and from school each day and preferred to return before dark, she'd write these up and mark workbooks before heading home. At home, she'd make worksheets and copies using a "jelly pad." 50 She preferred the workbooks and blackboard finding the "jelly pad" method to be messy and tedious.

Despite being so busy, on the rare occasion Celia got homesick. After a few months of teaching, she saved enough money to buy herself a bicycle upon which she used to ride home as often as possible to spend the weekend with her family in Alberta. She could usually rely on RCMP officers to transport her and her bicycle back to British Columbia on Sunday evenings.

Among the year's memorable events and activities, the Christmas concert stands out most for Celia. Cognizant of the refugees' limited English skills, she chose to have the students perform the fairy tale Hansel and Gretel. Celia assigned each child speaking lines, a song, or a recitation depending on their ability. Records ordered by mail helped students acquire the tunes. Celia also took "Hansel and Gretel home to Beaverlodge one weekend to practice with a neighbour who gave piano lessons" - a move that seems surprising today but illustrates the teacher-student bond in early- $20^{\text {th }}$-century rural communities. They walked about four miles through the bush to catch a train that transported them to Alberta and returned to BC late Sunday with an RCMP officer who was travelling up to Dawson Creek, just north of Tate Creek. The importance of the Christmas concert is underscored by the fact that Celia's mother and sisters attended it. "At the end of the concert, people just clapped and clapped and clapped until it was just embarrassing - you know - the enthusiasm just brought the roof down. They were just so pleased to see their children so happy and doing so well." To Celia, this enthusiasm indicated a well-deserved ease that began to characterize the community of refugees who sought to forget the turbulence they had fled in Europe. 
Celia noted that there were no disciplinary problems since the children - as well as their parents - were intent on learning English and succeeding in a new world. She also taught "English and Citizenship" to the adults one night a week to prepare them for their citizenship exams. Celia was somewhat intimidated by the group of "intelligent, accomplished, politically aware people." But she was encouraged by their motivation as, during the winter, most of them walked up to five miles in the dark, through sub-zero temperatures to get to the school.

The following year Celia married and because her husband was completing his studies at the University of British Columbia, she applied for a position in Surrey, a town just south of Vancouver. Her marriage took her first to Ontario and then to California, where, among other assignments, she opened a private school for severely disabled children who were ineligible for services in other institutions. She returned to Canada in 1977 and helped to spearhead the Yukon Teacher Education Program, jointly established by the University of British Columbia and the Yukon government. In 1980, she began a masters degree in Anchorage, Alaska, in special-needs education. Upon completion, she returned to BC's lower mainland where she taught special-needs and ESL children, retiring in 1989.

Although the formative years of her teaching career took place during World War II, like her precursor Amy, Celia made no attempt to engage her students in warrelated initiatives. She remembers undertaking marching drills during physical education class at Vancouver's Provincial Normal School but believes that the gesture was largely symbolic - a show of support for the war when many of her contemporaries were fighting overseas. At Tate Creek, her main goal for the children was to establish a sense of security and normality, a goal that she seems to have achieved as witnessed by the appreciative parents attending the Christmas concert.

Reflecting on her career, Celia credits the first year at Tate Creek with helping her develop survival skills. After that, things "certainly got easier. I survived...nothing was as hard as that school. But the support and enthusiasm of the kids and the parents... That helped." Now retired, she misses the children she worked with over the years. Her humanistic approach to teaching is summed up in the following: "I just didn't care if I taught a single solitary thing for the first couple of weeks and I just wanted them to want to come to school you know. Just like coming to school. I tried to do things that made them want to come. Once they wanted to come, I wanted them to accomplish something and feel proud of that."

\section{Conclusion}

The Tate Creek experiences of Amy and Celia are important for various reasons. First, this research illustrates how resourceful teachers in the first half of the twentieth century managed the schooling of immigrant children who lacked facility in English. Long before the birth of the term "ESL," teachers such as Amy and Celia intuitively applied many of pedagogical techniques advocated today by ESL specialists. By using songs and fairy tales, Amy and Celia built on what students already knew from their first language. The use of drama to retell and act out familiar stories in the new 
language are also recommended in today's ESL manuals of pedagogy, as is the labeling of common classroom items. The teachers also recognized the enormous strain on the children of working in a foreign language and wove breaks into the day by assigning less language intensive activities such as math and physical education. ${ }^{51}$

Second, this paper addresses O.L. Davis's challenge to examine "varieties of schooling in individual communities of different sizes and social compositions" during World War II. ${ }^{52}$ In doing so, this paper challenges the suggestion in some of the literature that throughout Canada all children and teachers in schools fervently engaged in nationalistic activities to support Canada's war effort. Amy considered her main task to teach the children and their parents English so that they could settle into a peaceful, secure life in Canada. By the time Celia arrived at Tate Creek, the students were basically conversant in English, so her main concern was to deliver the provincial curriculum required at each of the grade levels. As such, Celia's experiences were very much in keeping with other rural teachers who labored in multi-level oneroom schoolhouses.

Given the refugees' harrowing experiences in Czechoslovakia, neither teacher felt it appropriate to mobilize the community in Canada's war effort. In light of the refugees' sparse living conditions and their preoccupation with maintaining their own survival through learning English and farming an inhospitable land, it would have been inappropriate - and futile — to attempt to salvage materials or generate donations for the cause. As several researchers have argued, educational practices reflect the intersection of many factors, including the judgment of individual teachers and their relationships with students and parents. ${ }^{53}$ Indeed, societal interests and agendas are generally mediated by many intervening factors — including what a teacher feels is necessary and appropriate. ${ }^{54}$ There is no doubt that, historically, policy makers have intended national school systems to be key agents for promoting national consciousness. ${ }^{55}$ Future research examining communities of varying sizes and social structures has the potential to reveal the extent to which this intended goal was achieved during World War II.

\section{Notes}

1 I gratefully acknowledge the helpful feedback of Rebecca Coulter, Bob Gidney, and Wyn Millar on an earlier version of this paper presented at the Canadian History of Education biennial conference in Toronto, Ontario, 24 October 2010. I also thank two anonymous HSE reviewers whose suggestions strengthened the paper. Others settled in north central Saskatchewan in the St. Walberg area. W. Wanka, "The Sudeten Story," in Lure of the South Peace, ed. L. York (Dawson Creek: Peace River Block News, 1981), 948; J.F. Wagner, "British Columbia's Anti-Nazi Germans: the Tupper Creek Refugees," BC Studies, 39 (Autumn 1978), 6; "Sudeten Group Prepared to Sail For Peace River" Times, April 1, 1939, 1; 'Czech Emigrants to Undergo Rigid Examination," Globe and Mail, March 10, 1939, 15.

2 Jean Barman, The West Beyond the West: A History of British Columbia (Toronto, ON: University of Toronto Press, 1991), 261-2; J.L. Granatstein, Canada's War: The Politics of the Mackenzie King Government, 1939-1945 $2^{\text {nd }}$ Edition (Toronto: University of 
Toronto Press, 1990), 45 \& 186-87. In 1939 Canadian shipyards employed 3,500 workers; this grew to 80,000 during the war. See Pierre Berton, Marching as to War: Canada's Turbulent Years, 1899-1953 (Toronto: Doubleday Canada, 2001), 357. In addition to war equipment, Canada produced staggering amounts of food for the war effort. By 1942, Canada had sent Britain 90,000,000 bushels of wheat, 4,500,000 barrels of flour, 4,375,000 pounds of eggs as well as cheese, canned meats, herring, salmon and other seafood. See Barry Broadfoot, Six War Years, 1939-1945: Memories of Canadians at Home and Abroad (Toronto: Doubleday Canada, 1974), xii.

3 Robert S. Patterson, "Society and Education During the Wars and Their Interlude: 1914-1945," in Canadian Education: A History, eds. J.D. Wilson, R.M. Stamp, L.-P. Audet (Scarborough, ON: Prentice-Hall, 1970), 379-80.

4 Junior Red Cross chapters across the nation enrolled 875,000 girls who rolled bandages, learned first aid, and facilitated the shipment of non-perishable food and clothing for servicemen and children overseas. See Jeremy A. Keshen, Saints, Sinners, and Soldiers (Vancouver, BC: UBC Press, 2004), 203. See also F. Henry Johnson, A History of Public Education in British Columbia (Vancouver, BC: University of British Columbia Press, 1964), 123; Chuck Gosbee and Leslie Dyson, Glancing Back: Reflections and Anecdotes on the History of Vancouver's Public Schools (Vancouver, BC: Vancouver School Board, 1988), 48; "Lure of War Jobs Keeping Many from School," Vancouver Sun, 1 September, 1942, 22; Annual Report of the Public Schools of British Columbia (hereafter ARPS), 1939-40, B28-29.

5 "Ross Rifles for Trail Cadets: None for Vancouver" Daily Province, 22 November, 1940, 3; Tom MacInnes, "Rifle Practice In BC Schools," Vancouver Sun, 16 July, 1942, 4.

6 Annual Report of the Public Schools of British Columbia (ARPS), 1939-40, B29; "Victoria Orders Weekly Flag Salutes in All Schools of BC," Vancouver Sun, 5 September 1940, 17.

7 "Ross Rifles for Trail Cadets: None for Vancouver," Daily Province, 22 November, 1940, 3; Tom MacInnes, "Rifle Practice In BC Schools," Vancouver Sun, 16 July, 1942, 4.

8 ARPS, 1939-40, $\mathrm{B} 67$.

9 James London, "Lay Control in Public Education: The British Columbia School Trustees Association, 1905-1946," in School Leadership: Essays on the British Columbia Experience, 1872-1995, ed. Thomas Fleming (Mill Bay, BC: Bendall Books, 2001), 240.

10 Keshen, Saints, Sinners, and Soldiers, 203.

11 "Better Deal for Teachers, More Thorough Schooling: Perry Report," Victoria Daily Times, 4 February, 1943, 2.

12 Cynthia Comacchio, The Dominion of Youth: Adolescence and the Making of Modern Canada, 1920-1950 (Waterloo, ON: Wilfred Laurier University Press, 2006), 110; Gosbee and Dyson, Glancing Back, 48. See also ARPS, 1941-42, B56-B58 and B62; Serge Marc Durflinger, Fighting from Home: The Second World War in Verdun, Quebec (Vancouver BC: UBC Press, 2006), 120.

13 This assistance was enabled by a March 1942 regulation of the Council of Public Instruction, ARPS, 1941-42, B30. In BC, average daily attendance dropped to $86 \%$ of what it had been in the previous year $(103,192$ to 102,085). ARPS, 1941-42, 7. In the summer of 1944, as many as 30,911 high school graduates in the Toronto area sought full-time work rather than pursuing post-secondary studies. Comacchio, The Dominion of Youth, 110.

14 This is not only the case in Canada. Historians in the UK have generally argued that, in addition to changes to the curriculum, educators were charged with more and more social tasks. See, for example, Martin Lawn and Gerald Grace, Teachers: The Culture and Politics of Work (London, UK: The Falmer Press, 1987); Roy Lowe, Education and the Second World War: Studies in Schooling and Social Change (London: The Falmer Press, 1992); Brian Simon, Education and the Social Order 1940-1990 (London, UK: Lawrence and Wishart, 1991). In the United States, curricular changes 
were accompanied by more offerings of "practical" subjects to prepare students for the war effort. See Ronald D. Cohen, "Schooling Uncle Sam's Children: Education in the USA, 1941-1945," in Education and the Second World War: Studies in Schooling and Social Change; Gerard Giordano, Wartime Schools: How World War II Changed American Education (New York: Peter Lang, 2004). Sue Middleton has argued that in New Zealand the war prompted significant changes to curricula and prescriptions for classroom activities (such as tracing of wartime developments using maps and newspapers) that 'were punctuated by air-raid drills". See "Schools at War: a LifeHistory Analysis of Learning and Teaching in New Zealand, 1939-1949," Discourse: Studies in the Cultural Politics of Education 19,1 (1998): 53-74.

15 For a critique of publications on schooling and the war in the U.S., see O.L. Davis Jr., "The American Curriculum Goes to War, 1941-1945," Journal of Curriculum and Supervision 8, 2 (Winter 1993): 112-127.

16 ARPS, 1943-44, B52; ARPS, 1942-43, B50-52.

17 ARPS, 1943-44, B58. This shortage seemed to be particularly acute in Surrey. ARPS, 1943-44, B94 and ARPS, 1944-45, Y106.

18 Emilie L. Montgomery, "The war was a very vivid part of my life": The Second World War and the Lives of British Columbian Children in Children, Teachers and Schools In the History Of British Columbia, ed. Jean Barman, Neil Sutherland, and J. Donald Wilson (Calgary, AB: Detselig Enterprises Ltd., 1995), 162.

19 Ibid. In his autobiography of wartime schooling in Saint John, Jud Purdy recalls organizing a Junior Red Cross Branch, "being taught a course in first aid," "purchasing war savings stamps," and singing patriotic songs at school assemblies. Jud Purdy, "Where all the Children were United Empire Loyalists': Schooling in Saint John, N.B., in the 1930s and '40s," Historical Studies in Education 18,1 (2006): 85-96.

20 Mary Peate, Girl in a Sloppy Joe Sweater: Life on the Canadian Homefront During World War II (Toronto, ON: McLelland \& Stewart, 1989), 20.

21 Robert Collins, You Had to Be There: An Intimate Portrait of the Generation that Survived the Depression, Won the War, and Re-Invented Canada (Toronto: McLelland and Stewart, Inc., 1997), 78.

22 Elizabeth McLachlan, With Unfailing Dedication: Rural Teachers in the War Years (Edmonton, AB: NeWest Press, 2001), 75.

23 See, for example, Norah Lewis, "Isn't this a terrible war?' The Attitudes of Children to Two World Wars," Historical Studies in Education 7,2 (1995); and McLachlan, With Unfailing Dedication: Rural Teachers in the War Years.

24 In her study of how two schools in Ottawa experienced the war, Christine Hamelin argues that the "knitting clubs reflect the unity of purpose of the Canadian students, who took their efforts to help the less fortunate very seriously." See "A Sense of Purpose: Ottawa Students and the Second World War," Canadian Military History, 6,1 (Spring 1997), 37.

25 Patterson, "Society and Education During the Wars and Their Interlude: 1914-1945," 379.

26 See, for example, Patricia E. Roy, "Due to Their Keenness: Regarding Education, They Will Get the Utmost Out of the Whole Plan": The Education of Japanese Children in the British Columbia Interior Housing Settlements During World War Two' Historical Studies in Education 4, 2 (1992): 211-232.

27 See John J. Bergen, "The World Wars and Education Among Mennonites in Canada," Journal of Mennonite Studies 8 (1990): 156-172.

28 See, for example, Montgomery, "The war was a very vivid part of my life" and Comacchio, The Dominion of Youth.

29 Davis, "The American Curriculum Goes to War, 1941-1945," 122. See also Charles Dorn, “'A Woman's World': The University of California, Berkeley During the Second World War", History of Education Quarterly, 48,4 (2008): 536. 
30 J.F. Wagner, "British Columbia's Anti-Nazi Germans: the Tupper Creek Refugees" BC Studies, 39 (Autumn 1978), 3-19; W. Wanka, 'The Sudeten Story' in Lure of the South Peace, ed. L. York (Dawson Creek: Peace River Block News, 1981), 940-957.

31 Library and Archives Canada (LAC) Wilhelm (Willi) Wanka fonds, 1910-1992; A. Amstatter, Tomslake: History of the Sudeten Germans in Canada (Saanichton: Hancock House, 1978), 67.

32 Wagner, "BC’s Anti-Nazi Germans," 6; 'Sudeten Group Prepared to Sail For Peace River' Times, April 1, 1939, 1. Canada's Conservative opposition leader, R.J. Manion, opposed the scheme and openly criticized T.A. Crerar, Minister of Immigration, in the House of Commons. "Czech Emigrants to Undergo Rigid Examination," Globe and Mail, 10 March 1939, 15.

33 Amstatter, Tomslake, 69. "Sudeten Group Prepared to Sail," Times, 1 April 1, 1939.

34 The settlement boosted the finances of Canadian Pacific which had suffered during the Depression. J.L. McDougall, Canadian Pacific: A Brief History (Montreal: McGill University Press, 1968), 109.

35 Wanka, "The Sudeten Story," 952. See also "Sudeten Refugees Find New Life in Peace River," Times, November 4, 1939, 1.

36 E.C. Stacey, Peace Country Heritage (Saskatoon: Western Producer Book Service, 1974), 20. Wagner 'BC's Anti-Nazi Germans,' 10. Despite officials' opposition, by 1940, the settlers had organized themselves and established the Tate Creek Grocery Co-operative which replaced the commissary store operated by the Canadian Colonization Association. They soon expanded it to include livestock and dairy products. See 'Tate Creek Co-op', Galleria, Stories of the BC Co-Op Movement, 86, no date. http://bcics. uvic.ca/galleria/bc.php?tourtype $=1$ \&group $=8 \&$ story $=86$ [accessed May 9, 2006].

37 J. Calam, ed. Alex Lord's British Columbia: Recollections of a Rural School Inspector, 1915-1936 (Vancouver: UBC Press, 1991), 80.

38 Wagner, "BC’s Anti-Nazi Germans," 7; Wanka, "The Sudeten Story," 950.

39 "Sudeten-German Exiles Are Doing Well In BC." Province, October 28, 1944, 3.

40 "Sudetens Will Learn English," Daily Colonist, May 13, 1939, 6. Amstatter, Tomslake, 75.

41 Unless indicated, all information about Amy — including quotes - comes from interviews with her dated 22 March 2006 and 3 April 2006; from interviews with Ralph Burton 25 and 28 February, 2008 and Max Lorenz, 19 February, 2008. For an expanded version of Amy's story see Helen Raptis, "Bending the Bars of the Identity Cage: Amy Brown and the Development of Teacher Identity in British Columbia," History of Education 39, 2 (2010): 199-218.

42 Amy felt prepared since her normal school instructors had spoken at length about the hardships of working in rural districts. In 1939, 681(70\%) of British Columbia's 975 public elementary schools were rural. They employed $626(70 \%)$ women and 275 $(30 \%)$ men and were responsible for educating 120,459 (or 16\%) of the province's children. A sizeable number (4,362 or $23 \%$ ) of these children were reportedly "of foreign parentage." ARPS, 1939-1940, B9, B20 \& B13.

43 In grades 12 and 13, she served as her high school's first female student council president.

44 Amstatter, Tomslake, 126. Upon their arrival, the refugees were categorized as enemy aliens and fingerprinted. This required them to carry at all times their enemy aliens identity cards and landed immigrant cards and to report to the authorities weekly. This designation was dropped a year later due to heavy opposition from the settlers. See Margaret Melanie Drysdale, Three Times Betrayed: The Sudeten Germans of Tomslake, Upublished masters thesis, University of Victoria, 2005, 8 \& 96.

45 M. Drysdale, “Tate Creek School," Unpublished term paper, The Homeroom, no date. www.mala.bc.ca/homeroom/cntent/Schools/Public/Tatecrk.htm [accessed March 21, 2006]. 
46 Walter Schoen, a former student, recalled Miss Meade's disapproval of Amy in The Tupper Boys: A History of the Sudeten Settlement at Tomslake, BC (Victoria, BC: Trafford, 2004). Meade allegedly claimed that Amy "could not discipline the older boys, that she neglected her work and was too interested in the many single menv (74). Schoen implied that Meade's reaction to Amy was due to her harsh upbringing as the daughter of an officer in the British Army in India (72). Meade had a commanding presence, but tended to complain, was condescending to the settlers, and boiled the strap in a pot on the stove before administering it as punishment to the children, likely for the 'psychological effect' (78-79).

47 British Columbia Archives (BCA), GR-0122, BC Department of Education, School Inspectors Reports, 1939-1940, Reel B06678.

48 Unless indicated, all information about Celia - including quotes - comes from interviews with her dated 11 January, 2008 and 11 February, 2008. Information about Celia and the Christmas concert appeared in an earlier article. See Helen Raptis, "Remembering the School Christmas Concert," BC History 44, 1 (Spring 2011): 1-8.

49 The Catholic parish at Dawson Creek sent a priest to minister to the refugees soon after their arrival. Many of the settlers — including those of Jewish faith — had listed their religion as Catholic in the hopes of enhancing their claims for refugee status. However, as McConnell noted in his 1940 report to the Colonization Association, there was "little religion of any kind among the settlers." See Drysdale, Three Times Betrayed, 68.

50 Prior to the development of duplicating machines, teachers relied on the "jelly pad" known more officially as a "hectograph." It consisted of a cookie sheet with sides, a special gelatin for melting and a hectograph pencil for writing out a master worksheet. Once the melted gelatin was placed in the pan, a teacher would press the master worksheet onto it, written side down. The printing from the "master copy" would then transfer to the gelatin. Blank pieces of paper were then pressed into the gelatin to make copies. Although the initial copies came out clearly, the ink faded into the jelly over time requiring teachers to remove the jelly and boil it to start again. It was time consuming and the special hectograph pencils tended to wear out or break often. I am thankful to Wyn Millar and Bob Gidney for referring me to Edith Van Kleek's excellent description of jelly pads in The Way it Was: Vignettes from My One-Room Schools, ed. Thelma Jo Dobson (Calgary, AB: University of Calgary Press, 2007), 69. See also, McLachlan, With Unfailing Dedication, 124.

51 Barbara Law \& Mary Eckes, The More-Than-Just-Surviving Handbook: ESL for Every Classroom Teacher (Winnipeg, MB: Portage and Main Press, 2000); Sylvia Helmer, Look at Me When I Talk to You: ESL Learners in non-ESL Classrooms (Toronto, ON: Pippin Publishing, 1996).

52 Davis, "The American Curriculum Goes to War, 1941-1945," 122.

53 Teachers are motivated less by goals and interests of national or provincial policymakers than by "classroom events and relationships with students." Dan Lortie, School Teacher: A Sociological Study (Chicago: University of Chicago Press, 1975), 187. See also Kathleen Casey, I Answer with My Life: Life Histories of Women Teachers Working for Social Change (New York: Routledge, 1993), 163.

54 Amy von Heyking, Creating Citizens: History and Identity in Alberta's Schools, 1905 to 1980 (Calgary, AB: University of Calgary Press, 2006), 4.

55 George Tomkins, "Canadian Education and the Development of a National Consciousness: Historical and Contemporary Perspectives," in Canadian Schools and Canadian Identity, eds. Alf Chaiton and Neil McDonald (Toronto, ON: Gage Educational Press, 1977), 7. See also Bruce Curtis, "State of the Nation or Community of Spirit? Schooling for Civic and Ethnic-Religious Nationalism in Insurrectionary Canada" History of Education Quarterly, 43, 3 (Fall 2003): 325-349. 